\title{
Corporate Attributes and Corporate Disclosure Level of Listed Companies in Nigeria: A Post-IFRS Adoption Study
}

\author{
Kennedy Prince MODUGU ${ }^{1, *}$, Sharlywest Uwabor EBOIGBE ${ }^{2}$ \\ ${ }^{1}$ Department of Accounting, Faculty of Management Sciences, University of Benin, Benin City, Edo State, Nigeria \\ ${ }^{2}$ Department of Banking \& Finance, Faculty of Management Sciences, University of Benin, Benin City, Edo State, Nigeria \\ *Corresponding author: kennedy.modugu@uniben.edu
}

\begin{abstract}
This study examines the determinants of corporate disclosure level of listed companies in Nigeria. Specifically, the study investigates the relationship between two structure characteristics and corporate disclosure in Nigerian listed firms. The data used in the study were obtained from the annual reports of 60 companies listed on the Nigerian Stock Exchange from the various sectors of the Nigerian economy. The study covers the post International Financial Reporting Standards (IFRSs) adoption period of three years (2012 - 2014). The structure characteristics (independent variables) are firm size and leverage. Corporate disclosure (dependent variable) was disaggregated into mandatory, voluntary and total disclosure. The data were analysed using both descriptive statistics and the Ordinary Least Squares (OLS) regression. Findings from the descriptive statistics reveal that contrary to prior findings, there is a steady improvement in mandatory disclosure by Nigerian companies since the country's adoption of IFRSs. However, voluntary disclosure still remains relatively low.Our empirical results show a significant positive association between firm size and mandatory disclosure. The results also reveal a significant negative relationship between leverage and mandatory disclosure. Both leverage and firm size showed a significant positive relationship with voluntary disclosure. The combined effect of leverage and firm size show a significant positive relationship with total disclosure. Based on these findings, we recommend that the Financial Reporting Council of Nigeria and other regulatory agencies should intensify efforts towards enforcement of companies' compliance with the requirements of IFRSs and other relevant statutory provisions.
\end{abstract}

Keywords: corporate attributes, corporate disclosure, IFRS adoption, Nigeria

Cite This Article: Kennedy Prince MODUGU, and Sharlywest Uwabor EBOIGBE, "Corporate Attributes and Corporate Disclosure Level of Listed Companies in Nigeria: A Post-IFRS Adoption Study.” Journal of Finance and Accounting, vol. 5, no. 2 (2017): 44-52. doi: 10.12691/jfa-5-2-3.

\section{Introduction}

Global corporate accounting scandals like Waste Management in 1998, Enron in 2001, WorldCom in 2002, Tyco in 2002, HealthSouth in 2003, Freddie Mac in 2003, American Insurance in 2005, Lenman Brothers in 2008, Saytam in 2009, Banco Espirito Santo (BES) in 2014, Toshiba in 2015 and Turing Pharmaceutical in 2015, have raised serious concerns about corporate reporting globally. Similar scandals in companies such as African Petroleum, Afribank, Cadbury and Unilever were also recorded in Nigeria at different times. The common features of these scandals include suppression of losses, inflation of income, understatement of expenses, wrong classification of transactions, and concealment of vital corporate information.

Although, the Enron scandal saw major reforms in corporate governance and reporting practices such as the enactment of Sarbanes-Oxley (SOX) Act (2002); compulsory certification of fairness of financial reporting by chief executive officers (CEOs) and chief financial officers (CFOs); establishment of Public Companies Accounting
Oversight Board (PCAOB); improvements in accounting and auditing standards; prescription of serious sanctions for violation of regulatory requirements; and the international cooperation among professional accounting bodies, corporate managers have continued to devise newer means of subverting the systems. These scandals as well as the continuous breaches by CEOs and CFOs have led to the increasing demand for more transparent disclosure by companies across the globe with a view to sufficiently make the operations of public companies more visible to the multiplicity of users of corporate reports. This continuous demand for credible corporate reports by stakeholders is occasioned by the primacy of corporate report as a principal tool for the communication of information to external users, assessment of economic performance and condition of an enterprise in order to monitor management's actions and enhance the quality of decision making [30].

Nigeria has since 2012 joined other countries in reporting their financial statements under the International Financial Reporting Standards (IFRS). In order to examine the extent of companies' compliance with the standards, a study on accounting disclosure following the 
adoption of the global reporting standards is imperative. Therefore, this study is undertaken to determine the extent to which firm structure characteristics such as firm size and leverage influence corporate disclosure in the postIFRS adoption period in Nigeria.

\section{Review of Literature and Hypotheses Development}

\subsection{Concept of Corporate Disclosure}

The concept of corporate disclosure seems amorphous. Attempts at conceptualizing and measuring it have not yielded a universal approach for researchers. For example, Abu-Nassar [2] argues that defining disclosure is difficult and may be arbitrary. This is because we are measuring people's needs, perception, and attitudes which are qualitative rather than quantitative [8]. Cooke and Wallace (1989) assert that disclosure is an abstract concept that cannot be measured directly. It does not possess inherent characteristics by which one can determine its intensity or quality like the capacity of a car.

One of the earliest definitions of disclosure is given by Kohler (1957). He describes disclosure as a clear showing of the fact or conditions on the balance sheet or other financial statements, in the footnote thereto, or in the audit report. Also, Choi [15] defines disclosure as "the publication of any economic datum relating to a business enterprise, quantitative or otherwise, which facilitates the making of economic decisions" (p. 123). According to him, economic data consist of information which prunes the uncertainty that is characteristic of the outcome of future economic events and that improved disclosure is a function of increased quantity and quality of economic data available to investors through financial statements. Gibbins, Richardson and Waterhouse [20] define disclosure as "any deliberate release of financial information, whether numerical or qualitative, required or voluntary, via formal or informal channels" (p.122).

Parker [45] defines disclosure as the reporting of financial and non-financial information to users of accounting reports, especially to investors, which can be made according to legislation or accounting standards or can be voluntary. Cooke [17] "states that disclosure comprises mandatory and voluntary items of information provided in the financial statements, notes to the accounts, management's analysis of operations for the current and forthcoming year and any supplementary information” (p.231). Abdulrahman [1], in reviewing the preceding definitions of disclosure posits that corporate disclosure is a wide-ranging term which goes beyond the annual reports. He, therefore, narrowed it down to suit his study. According to him, disclosure is the publication of any type of information through the corporate annual reports that are necessary, relevant and material to the various user groups in making their judgements and decisions about a company. Lee [33] believes that disclosure refers to an accurate and timely release of information about the business strategy, financial performance and corporate governance to the general public by a company.

According to Al-Zarouni [8], "the definition of corporate disclosure varies and the concept itself covers a wide area. It goes beyond the corporate annual reports to cover information outside the financial statements such as discussion of competition, economic statistics and analysis of company" (p.45). Owusu-Ansah [42] and Wallace and Naser (1995) see disclosure as a communication of economic information, whether financial or non-financial, quantitative or otherwise concerning a company's financial position and performance. Disclosure results in a combination of mandatory and voluntary items that constantly interact with each other. Mandatory disclosure is a company's obligation to disclose a minimum amount of information in corporate reports [42,52], whereas voluntary disclosure is a provision of additional information when mandatory disclosure is unable to provide a true state of a company's value and managers' performance. Voluntary disclosure is the release of additional information about a firm in excess of the statutorily required information.

More recently, Solomon [49] describes disclosure as a whole array of different forms of information produced by companies such as the annual report and all forms of voluntary corporate communications. Okike, Adegbite, Nakpodia \& Adegbite [38] observe that the annual report and accounts of a company act as the channel of communication from the directors to shareholders and are important for corporate governance because these reports provide the means by which the directors are made accountable to the shareholders.

The existing definitions of disclosure are a testament to the broadness and diversity of the concept, as prior researchers have advanced definitions suitable for the scope of their respective studies. For over four decades of research into corporate disclosure, the concept was bereft of any known theory until Healy and Palepu [23] as well as Omran and El-Galfy [40] proposed a list of theories for disclosure. This according to Abdulrahman [1] is due to the abstract nature of disclosure which may mean several things to several people. This is why different researchers view the concepts from different perspectives. These perspectives include disclosure adequacy [8,12] and disclosure quality $[36,48]$.

In this study, disclosure is defined as the fair presentation of an entity's financial or non-financial, mandatory or voluntary information that is useful to stakeholders' decision making. Fundamentally, for the information to be useful, it must be relevant and faithfully represents that which it purports to represent. In addition, the information is enhanced by the qualities of comparability, verifiability and understandability.

\subsection{Current Level of Disclosure in Nigeria}

Nigeria accounts for nearly one-fourth of Sub-Saharan Africa's population and is the seventh most populous country in the world ([57], August 2013). As of April 2014, it was recognized as the continent's largest economy and most populous country ([50]; Bloomberg. 7 April 2014). Ranking 13th in the world for its oil production, Nigeria is Africa's largest producer and holds the second highest proven oil reserves on the continent, after Libya [56].

The Government of Nigeria requested the World Bank in 2010 to conduct a second Report on the Observance of 
Standards and Codes, Accounting \& Auditing (ROSC A\&A). This ROSC A\&A review was conducted to assess the status of implementation of the 2004 ROSC A\&A Country Action Plan and identify ways to strengthen the institutional framework underpinning accounting and auditing practices and improve financial reporting in Nigeria. The ROSC exercise was conducted through a participatory process involving key stakeholders and led by the country authorities [55].

The report found that there has been limited implementation of the 2004 Country Action Plan and limited improvement in financial reporting practices in Nigeria. Nigerian authorities have implemented only 6 out of 14 action plans emanating from the 2004 review leaving significant areas yet to be addressed [55]. A number of companies exploit the loopholes in Nigerian accounting and auditing standards; weak capacity of the regulatory bodies and weak enforcement; and creative accounting techniques to boost their balance sheets. These weaknesses in accounting and audit practices contributed to Nigeria's banking sector crisis of 2009. Given the magnitude of the costs of the crisis (between N1.5 - N2 trillion), the government is focused on improving A\&A. Since 2009 the Central Bank of Nigeria, Securities and Exchange Commission and other bodies have taken considerable steps to improve financial reporting and disclosure standards [55].

The report of the ROSC Team also revealed a substantial noncompliance with accounting standards by entities in Nigeria. Information on "compliance gaps"difference between applicable accounting standards and actual practice demonstrates weaknesses of corporate financial reporting [55]. The review which centred on published financial statements, mainly involved an examination of 40 sets of financial statements of major listed companies against a checklist of selected disclosure requirements under the Nigerian Accounting Standards Board-issued Statement of Accounting Standards (NASB, SAS). In areas where SAS do not exist, the relevant IAS/IFRS disclosure requirements were included in the checklist. The review also involved interviews with experienced corporate accountants, practicing auditors, academics, members of professional bodies, and regulators. The exercise showed noncompliance with important disclosure requirements. Areas, where significant noncompliance was observed are presented below:

Disclosures: Many companies avoided full disclosure of information in published financial statements as per requirements of the applicable Statement of Accounting Standards. More importantly, the observed accounting policies in line with the SAS requirements were hardly presented in a proper manner.

Related Party Transactions: Detailed disclosures in line with the requirements of the relevant accounting standard were generally absent in the reviewed financial statements. For instance, the ownership structure of many companies suggested that related parties and related party transactions existed, but the notes to the financial statements of these companies showed either very limited or no disclosures with regard to related parties and related party transactions.

Revenue Recognition: Many companies did not properly disclose the accounting policy on revenue recognition. In this context, some analysts and other users of financial statements in the country have opined that many companies resort to overstatement or understatement of revenues in order to show the accounting profit at the desired level.

Employee Benefits: Although many companies have employee pension plans, almost all of them failed to disclose information required by the relevant accounting standard. No disclosure was made as to whether actuarial or any other forms of valuations had been made to quantify outstanding liabilities for employees' postemployment benefits. According to the knowledgeable accountants and auditors in the country, in many companies, the full liability for employee benefit expenses is not recognised on an accrual basis.

Segment Reporting: Most companies that apparently had business segments and geographical segments did not comply fully with the segment reporting requirements.

Proponents of IFRS adoption are of the view that their adequate application in the preparation and presentation of financial statements will improve the quality of corporate reporting and increase the value relevance of accounting information. However, how well this adoption translates into the desired objective is still a subject of debate. This is because mere adoption does not automatically guarantee compliance by firms if the institutions saddled with the responsibility of enforcement under the new regime are not different from those under the local generally accepted accounting practices (GAAP) regime which were considered weak. Again, most financial reporting regulatory agencies do not have mechanisms for monitoring and enforcements of standards and rules, and where they exist at all, it is either they are weak or are enforced in the breach [55].

Okike et al [38] argue that despite the varieties of policies and regulatory interventions, the practice of corporate governance in Nigeria which is the fulcrum of corporate management and reporting is grossly inadequate. Okike et al [38] citing several studies highlighted some factors responsible for the weakness of corporate governance in Nigeria to include corruption [5,32]; weak regulatory and enforcement mechanism [26]; multiplicity of codes [41,54]; disclosure and transparency issues [44]; weak shareholder activism [4,9]; weak institutional arrangement [3]; passive attitude of government (Ogbeide, 2012); amongst many others. As a consequence, the impact of these challenges has been severe in the business environment. For instance, foreign investors are not encouraged to invest in the country, thereby hampering economic growth potentials $[5,6]$.

Given the reported weakness in the regulatory framework and enforcement mechanism, the assumption that Nigerian firms disclose all required information does not hold. Hence the need to assess the current level of disclosure of Nigeria firms under the IFRS regime.

\subsection{Firm Structure Variables and Corporate Disclosure}

Firm structure variables describe a firm on the basis of its underlying structure and are likely to remain stable over time [31,52]. They consist of leverage and firm size [47]. They are discussed hereunder. 


\subsubsection{Leverage}

Companies depending on debts should satisfy the needs of creditors through disclosing more information about the company's performance [47]. Leverage describes the debt in the financial structure of a firm and measures the long-term risk implied by that structure [25]. Firms employing more debt financing provide extensive accounting disclosure than equity-financed firms and leverage reveals the balance between shareholders' fund and debt-holders fund [24,25,46,53]. Accordingly, companies with high leverage levels are likely to disclose more information than less leveraged ones. Leverage has been measured by debt ratio; total liabilities to total assets [7], and debt to equity ratio [13,39,52].

Empirical evidences from previous studies have shown inconclusive results concerning the effects of leverage on corporate disclosure. While some studies have found a significant association between leverage and the level of disclosure (for example, Malone, Fries \& Jones, 1993; Hossain, Tam \& Adams, 1994; Jaggi \& Low 2000; Archambault \& Archambault 2003; Eng \& Mak 2003), other studies have reported no such association (for example, Chow \& Wong-Boren, 1987; Ahmed \& Nicholls, 1994; Wallace et al. 1994; Wallace \& Naser 1995; Alsaeed 2006). Some studies reported a negative relationship (for example, Meek, Robert \& Gray, 1995; Zarzeski, 1996).

From the foregoing, we raise the following hypothesis:

$\mathrm{H}_{1}$ : there is no significant relationship between leverage and corporate disclosure.

\subsubsection{Firm Size}

According to Hassan, Giorgioni and Romilly (2006), "firm size is considered to be an important determinant of corporate disclosure practice” (p. 48). Several studies $[7,13,47,52]$ argue that the direction of the relationship between company size and disclosure level may be either positive or negative. The negative relationship is supported by the fact that large companies are more visible and as such, may be subjected to political attacks such as the threat of nationalization. These companies may then be forced to disclose less detail in their annual reports in order to reduce the likelihood of political action.

Conversely, large companies may disclose more information as they are more subject to scrutiny by the public than small companies [13]. Also, large companies may reduce their cost of capital through increased disclosures [31]. Moreover, large companies can disclose more information at low costs as they have enough resources to collect and analyze data [7]. The incremental cost of supplying nonproprietary data to the public is likely to be minimal for large firms [43]. In addition, gathering and disseminating information are costly practices and may be too burdensome for small firms [13]. Company size can be proxied by total assets [7,13,37,39,52], total sales [52].

From the foregoing, we raise the following hypothesis:

$\mathrm{H}_{1}$ : there is no significant relationship between firm size and corporate disclosure.

\section{Theoretical Framework}

This paper is hinged on the Agency Theory. Agency Theory states that when one party (the principal) delegates decision-making powers to another party (the agent) under a contract, a principal-agent relationship arises (Jensen \&Meckling, 1976; Clarke, 2004). Jensen and Meckling (1976) define the principal-agent relationship as a contract under which one or more persons (principals) engage another person (the agent) to perform some services on their behalf, which involves giving some decision-making authority to the agent. Whereas the 'article of faith' in an agency arrangement is for both the principal and the agent to work towards the interest of the principal, information asymmetry and greed lure management into pursuing personal objectives instead of those of the principal. This conflict of interest or goal incongruence results in agency problem $[16,18,19,29]$. From the business perspective, the agency relationship arises when shareholders (who are the owners of resources) delegate the administration of an entity to management (who administers the enterprise), thus making management the agent of the shareholders. In this kind of relationship, the expectation is that the agent (management) will pursue the shareholders' wealth maximisation objective [29].

The agency problems common in agency relationship include management's appropriation of bogus pay and sundry fringe benefits to itself, management's involvement in risky investment projects, management's pursuit of personal objectives instead of those of the principal, or deliberate choice to operate sub-optimally [21,29].

Besides the shareholder-management relationship, agency relationship may also be in the form of shareholder-lender relationship. This the shareholders do through management. Lenders entrust their money to shareholders, with the expectation that shareholders will honour the loan covenants agreed between the two parties. However, what may happen is that the shareholders, through management, may pay themselves excessive dividends or take on more loans contrary to the existing covenants with the lenders [21,29].

The Agency Theory is relevant to this study because the sampled companies are those listed on the Nigerian Stock Exchange. The managements of these companies are separated from the owners (shareholders) and are required by the respective legal and regulatory authorities to render the account of stewardship to the shareholders at the annual general meetings. In fulfilling this obligation, managements employ the accounting standards and other relevant provisions to disclose information to the shareholders.

Also, Ibrahim [25] argues that Agency Theory has a direct nexus with corporate disclosure research because corporate disclosure presents an ample opportunity to apply positive agency theory. This is due to the fact that managers (agents), by the nature of their position in the firm, have better access to company's information and ceteris paribus can make timely, reliable and credible communication to the market to optimise the value of the firm. Through financial reporting, they communicate to the users of financial reports information that is useful in making informed economic decisions among alternative uses of scarce resources. On the contrary, these managers may, due of their selfish interests, fail to make proper disclosure or indulge in non-disclosure of important information to the users. This leads to information asymmetry. Such practices will not be in the best interests of shareholders (principal). Consequently, this may result 
in a higher cost of capital and lower value of shareholders' investments.

\section{Methodology}

\subsection{Research Design, Sample and Data}

This study adopted the longitudinal research design. This is because it is useful in the studying of the current state of a unit or a group of items over a period of time. The content analysis approach which involves the construction of disclosure checklist from a list of annual report items was used. A disclosure index was developed from the checklist and used for the study. Historically, Cerf [14] is the first researcher who conducted an empirical study using a disclosure index. He developed an index consisting of 31 items, each of which was scored on a scale of 1 to 4 on the basis of interviews with financial analysts. Cerf's approach, with extensions and modifications, has been used widely in many other studies (for example, Wallace, 1988; Lang \& Lundholm, 1993; Alsaeed, 2006; Umoren, 2009; Al-Zarouni, 2008; Qu, 2011; Ibrahim, 2014) to examine the adequacy of corporate financial disclosure in different countries. Considering a given list of items, the value of the index for a particular company is obtained by dividing the number of information items disclosed by that company by the total number of information disclosure items that might be disclosed. The checklist for the study contains a total of 102 disclosure items.

The study population consists of the 189 listed companies on the Nigerian Stock Exchange at $31^{\text {st }}$ December 2014 (Factbook, 2014). In estimating the sample size, the Yamane ([58] formula was used. The formula was chosen because of its simplicity and is considered as the most popular sampling design technique [27]. In addition, the population is finite, making it amenable to the formula. This formula is given as:

$$
n=\frac{N}{1+N(e)^{2}}
$$

Where: $\quad \mathrm{n}=$ sample size

$\mathrm{N}=$ population

$\mathrm{e}=$ error limit (0.05 on the basis of $95 \%$ confidence level)

Therefore, $\mathrm{n}=189 /\left[1+189\left(0.05^{2}\right)\right.$

$$
\begin{aligned}
& n=189 / 1+189(0.0025) \\
& n=189 / 1.4725 \\
& n=128
\end{aligned}
$$

Based on the above sample of 128 firms, the simple random sampling technique was then adopted in selecting 60 firms from a stratified sample of thirty industries trading on the Nigerian Stock Exchange between $1^{\text {st }}$ January 2012 and 31 $1^{\text {st }}$ December 2014. This was to ensure that the relevant sectors have equal chances of being represented. The choice of 2012 to 2014 was informed by the fact that going by the roadmap for the adoption of IFRS by Nigerian companies which began on January 1, 2012 and ended on January 1, 2014, all public listed entities are expected to have fully complied by the year ended $31^{\text {st }}$ December 2014.

\subsection{Model Specification and Variable Measurement}

$$
\text { TDISC }_{\text {it }}=\eta_{0}+\eta_{1} \mathrm{LEV}_{\text {it }}+\eta_{2} \text { FSIZE }_{\text {it }}+\mu_{\text {it }} .
$$

Where:

TDISC $=$ Total corporate disclosure

LEV = Leverage

FSIZE $=$ Firm size

$\mu=$ the stochastic error term,

$\mathrm{i}=$ number of sampled firms $(1,2, \ldots \mathrm{n})$,

$\mathrm{t}=$ time period of the sample companies.

The a priori expectations are:

$\eta_{1}>0$; implying that the higher the LEV, the higher the disclosure level,

$\eta_{2}>0$; implying that the higher the FSIZE, the higher the disclosure level,

The model was adapted from previous empirical studies $[8,14,25,51]$ on corporate disclosure with some modifications.

Table 1. Operationalisation of Variables

\begin{tabular}{|c|c|c|c|c|}
\hline S/N & Variables & Codes & Measurement & $\begin{array}{c}\text { A priori } \\
\text { sign }\end{array}$ \\
\hline 1 & $\begin{array}{c}\text { Total } \\
\text { disclosure } \\
\text { index }\end{array}$ & TDISC & $\begin{array}{c}\text { Summation of both } \\
\text { mandatory and } \\
\text { voluntary disclosure } \\
\text { indexes }\end{array}$ & \\
\hline 2 & Leverage & LEV & $\begin{array}{c}\text { Long-term debt to } \\
\text { total assets ratio for } \\
\text { financial } \\
\text { institutions and } \\
\text { debt-equity ratio for } \\
\text { non-financial } \\
\text { companies }\end{array}$ & + \\
\hline 3 & Firm size & FSIZE & $\begin{array}{c}\text { Log of total sales at } \\
\text { year end }\end{array}$ & + \\
\hline
\end{tabular}

Source: Researchers’ Compilation, 2016.

\section{Empirical Results}

The study utilizes both descriptive statistics and the Pooled Ordinary Least Squares (OLS) estimation. The use OLS is a simple way to examine the sensitivity of the results to alternative specifications [10] and allows for greater flexibility in modelling differences in sample specific behaviour [22]. The results are presented and analyzed below:

\subsection{Descriptive Statistics}

Figure 1 shows the average disclosure index for the distribution in the IFRS period covered in the study. As observed, for 2012, the average mandatory disclosure index was 0.692 and then increased to 0.7036 in 2013 and to 0.7431 in 2014 . The average index score suggest that most companies in the distribution did not fair to poorly in implementation of IFRS for 2012 reporting year. For voluntary disclosures (VDISC), the average index for 2012 was 0.445 , while 2013 and 2014 had the same index of 0.4533 . The results suggest that the pattern of voluntary disclosure in annual reports is still quite low arguably so because it is voluntary. There may also be a tendency for this category of disclosures to be largely repetitive over 
time. For total disclosures (TDISC), the average index for 2012, 2013 and 2014 are 0.6679, 0.6791, and 0.7193 respectively. The result shows some level of improvement in total disclosures emanating basically from improvements in mandatory disclosures. This may suggest that most companies have improved their disclosures subsequently after initial 2012 reporting year.
Table 2 shows the regression result of the effect of firm structure on corporate disclosure. As can be observed, three firm structure variables (FSIZE, LEV and FS-factor score) were regressed on mandatory disclosure, voluntary disclosure and total disclosure. We first regressed the firm structure variables and then a firm structure index derived using factor scores.

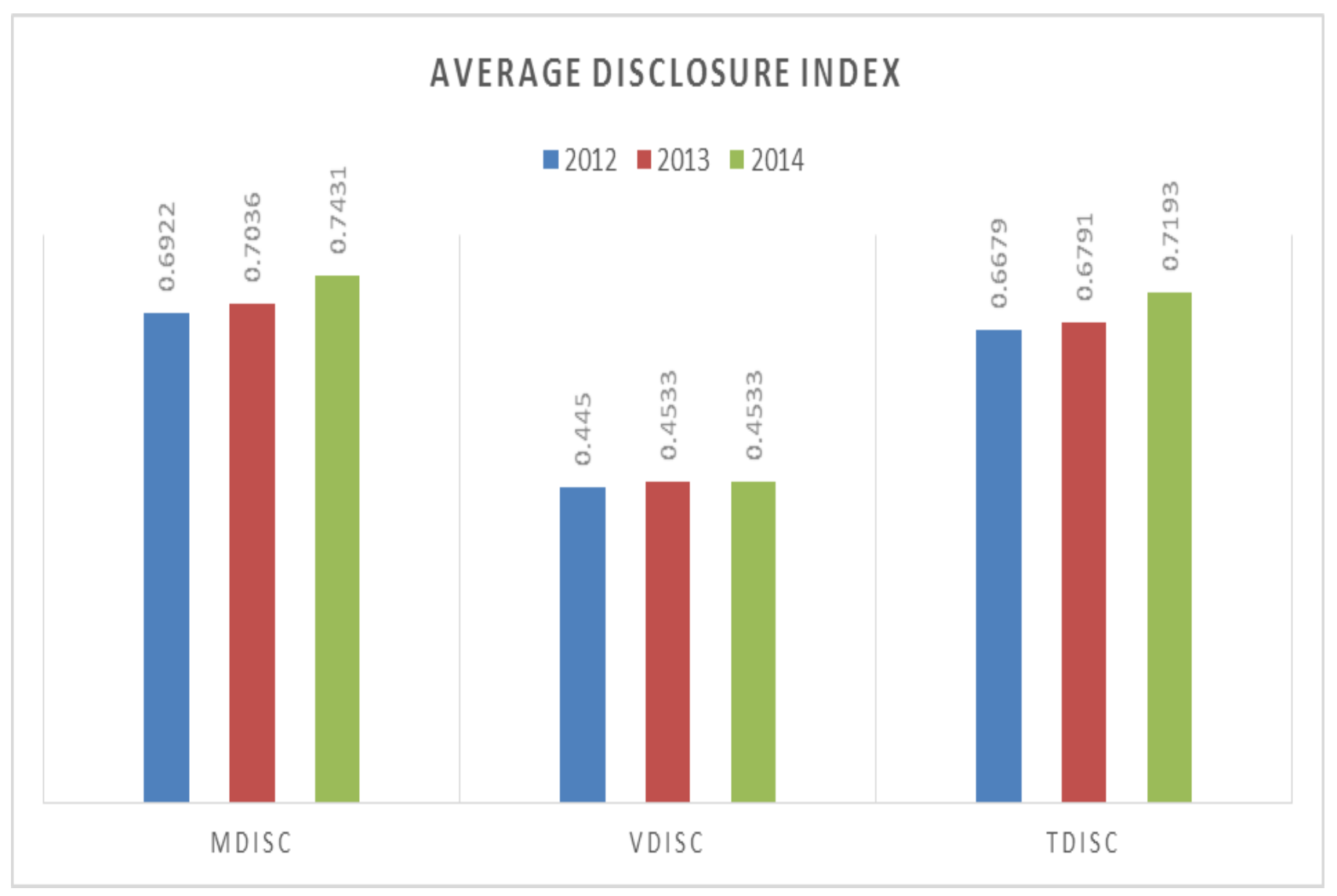

Figure 1. Average Disclosure Index (Source: Researchers' Compilation (2016))

Table 2. Regression Results

\begin{tabular}{|c|c|c|c|c|c|c|}
\hline Variable & MDISC & VDISC & TDISC & MDISC & VDISC & TDISC \\
\hline C & $\begin{array}{c}41.0858^{*} \\
\{0.0820\} \\
(0.000)\end{array}$ & $\begin{array}{c}2.324^{*} \\
\{0.0166\} \\
(0.0000)\end{array}$ & $\begin{array}{c}44.563^{*} \\
\{0.2166\} \\
(0.000)\end{array}$ & $\begin{array}{c}63.9275^{*} \\
\{0.0026\} \\
(0.000)\end{array}$ & $\begin{array}{c}4.2923^{*} \\
\{0.0141\} \\
(0.000)\end{array}$ & $\begin{array}{c}68.244 * \\
\{0.0118\} \\
(0.000)\end{array}$ \\
\hline FSIZE & $\begin{array}{c}1.3672^{*} \\
\{0.0065\} \\
(0.000)\end{array}$ & $\begin{array}{c}0.1162^{*} \\
\{0.0013\} \\
(0.000)\end{array}$ & $\begin{array}{c}1.4314 *\{0.0181 \\
(0.000)\end{array}$ & & & \\
\hline LEV & $\begin{array}{c}-0.1300^{*} \\
\{0.0065\} \\
(0.000)\end{array}$ & $\begin{array}{c}0.0293^{*} \\
\{0.0019\} \\
(0.000)\end{array}$ & $\begin{array}{c}-0.1041^{*} \\
\{0.003\} \\
(0.000)\end{array}$ & & & \\
\hline FS-Index & & & & $\begin{array}{c}0.5282 * \\
\{0.0369\} \\
(0.0286)\end{array}$ & $\begin{array}{c}-0.1551^{*} \\
\{0.0108\} \\
(0.000)\end{array}$ & $\begin{array}{c}0.3328^{*} \\
\{0.0097\} \\
(0.000)\end{array}$ \\
\hline $\mathrm{R}^{2}$ & 0.469 & 0.690 & 0.5134 & 0.4182 & 0.5705 & 0.5112 \\
\hline ADJ $R^{2}$ & 0.464 & 0.687 & 0.5079 & 0.4127 & 0.5652 & 0.5056 \\
\hline F-Stat & 78.476 & 197.35 & 93.382 & 32.873 & 13.4339 & 20.106 \\
\hline P(f-stat) & 0.000 & 0.000 & 0.000 & 0.000 & 0.000 & 0.000 \\
\hline D.W & 2.1 & 1.8 & 2.1 & 1.9 & 1.83 & 2.2 \\
\hline S.E Regression & 7.8547 & 1.378 & 8.1082 & 8.0475 & 1.4095 & 8.4516 \\
\hline Mean of dependent var & 133.2809 & 11.589 & 175.03 & 120.7059 & 9.0935 & 117.051 \\
\hline
\end{tabular}

Source: Researchers’ Computation (2016) * sig at 5\% \{ \} standard errors, ( ) p-values. 
For mandatory disclosure (MDISC), the model properties reveal that the coefficient of determination $\left(R^{2}\right)$ and Adj $R^{2}$ are 0.469 and 0.464 respectively. These values suggest that the model explains about $46.9 \%$ of systematic variations in mandatory disclosures with an adjusted value of $46.4 \%$ after controlling for degrees of freedom. The F-stat (78.476) and p-value (0.000) indicate the acceptance of the hypothesis of a significant linear relationship between the variables (dependent and independent) at $5 \%$ level of significant while the D.W statistic of 2.1 indicates that a serial correlation presence in the residuals is unlikely. The effect of FSIZE is positive (1.3672) and significant at 5\% level $(p=0.000)$. While the effect of LEV is negative $(-0.1300)$ and significant at $5 \%$ level $(\mathrm{p}=0.000)$.

For voluntary disclosure (VDISC), the model properties reveal that the coefficient of determination $\left(R^{2}\right)$ and Adj $\mathrm{R}^{2}$ are 0.690 and 0.687 respectively. These values suggest that the model explains only about $69.0 \%$ of systematic variations in mandatory disclosures with an adjusted value of $68.7 \%$ after controlling for degrees of freedom. The Fvalues confirm that the hypothesis of a significant linear relationship between the variables (dependent and independent) cannot be rejected at 5\% level while the D.W statistic of 1.8 indicates that a serial correlation presence in the residuals of the model is unlikely. Evaluating the effect of the firm structure variables, the result reveals that FSIZE is positive (0.1162) and significant at $5 \%$ level $(\mathrm{p}=0.000)$ while the effect of LEV is positive $(0.0293)$ and significant at $5 \%$ level $(p=0.000)$.

For total disclosure (TDISC), the model properties reveal that the coefficient of determination $\left(\mathrm{R}^{2}\right)$ and Adj $\mathrm{R}^{2}$ are 0.5153 and 0.5079 respectively. These values suggest that the model explains only about $51.53 \%$ of systematic variations in mandatory disclosures with an adjusted value of $50.79 \%$ after controlling for degrees of freedom. The F-values confirm that a significant linear relationship between the variables (dependent and independent), while the D.W statistic of 2.1 indicates that the presence of serial correlation in the residuals of the model is unlikely. Evaluating the effect of the firm structure variables on total disclosures, the result reveals that FSIZE is positive (1.4314) and significant at 5\% level $(p=0.000)$ while the effect of LEV is negative $(-0.1041)$ and significant at $5 \%$ level $(\mathrm{p}=0.000)$. Consequently, we therefore accept the alternative the hypotheses that there are significant relationships between leverage and firm size and corporate disclosure.

Using the firm structure index, the model properties for MDISC; $\mathrm{R}^{2}=0.4182$, Adj $\mathrm{R}^{2}=0.4127$, F-stat $=32.873$ and $\mathrm{D} . \mathrm{W}=1.9$. The effect of FS-Index is positive (0.5282) and significant at $5 \%$ level $(\mathrm{p}=0.0286)$. For VDISC, the model properties are; $\mathrm{R}^{2}=0.5705$, Adj $\mathrm{R}^{2}=0.5652$, F-stat $=13.433$ and D.W $=1.83$. The effect of firm structure-index is negative $(-0.1551)$ and significant at $5 \%$ level $(\mathrm{p}=0.000)$. For TDISC, the model properties are; $\mathrm{R}^{2}=0.5112$, Adj $\mathrm{R}^{2}=0.5056$, F-stat $=20.106$ and D.W $=2.2$. The effect of firm structure-index score is positive (0.3328) and significant at $5 \%$ level $(\mathrm{p}=0.000)$.

\section{Discussion of Findings}

The results show high level consistency in the performance of leverage in influencing voluntary disclosure. If was however found that leverage is inversely proportional to mandatory and voluntary disclosure. The results are in tandem with theoretical expectations that companies depending on debts should satisfy the needs of creditors through disclosing more information [47]. Also, firms employing more debt financing provide extensive accounting disclosure than [24,25,46,53]. Empirical evidence from previous studies has shown inconclusive results concerning the relationship between leverage and corporate disclosure. While some studies have found a significant association between high leverage and the level of disclosure (e.g., Malone, Fries \& Jones, 1993; Hossain, Tam \& Adams, 1994; Jaggi \& Low 2000; Archambault \& Archambault 2003; Eng \& Mak 2003), other studies have reported no such association (e.g., Chow \& Wong-Boren, 1987; Ahmed \& Nicholls, 1994; Wallace et al. 1994; Wallace \& Naser 1995; Alsaeed 2006). Some studies reported a negative relationship (e.g. Meek, Robert \& Gray, 1995; Zarzeski, 1996).

For firm size, our results showed high level consistency in the performance of firm size in influencing corporate disclosure. The results also agree with the a priori expectations. According to Hassan, Giorgioni and Romilly (2006), firm size is considered to be an important determinant of corporate disclosure practice. However, the direction of the results has been largely inconclusive in the literature especially regarding the direction of the relationship. Several studies [7,13,47,52] argue that the direction of the relationship between company size and disclosure level may be either positive or negative. In line with our finding large companies may disclose more information as they are more subject to scrutiny by the public than small companies [13]. Moreover, large companies can disclose more information at low costs as they have enough resources to collect and analyze data [7]. The incremental cost of supplying nonproprietary data to the public is likely to be minimal for large firms [43].

Furthermore, unlike prior studies in this regards, this study developed a firm structure index using factor scores generated from principal component analysis. The results indicate that for MDISC, Firm structure index (FS-index) is positively significant. For voluntary disclosure (VDISC), Firm structure index (FS-Index) is negatively significant. While for TDISC, Firm structure index (FS-Index) is positively significant. Overall, the index shows high consistency across all categories of corporate disclosure. Consequently, we fail to accept the hypothesis there is no significant relationship between firm structure variables and corporate disclosure.

\section{Conclusion and Recommendations}

The relationship between firm structure variables and corporate disclosure has been examined by prior studies. These studies record conflicting findings regarding the direction and significance of the association between firm structure variables and corporate disclosure levels. In this study, we moved a step further to examine not only the individual relationships, but the combined effect of leverage and firm size (represented by the factor score of both variables) on the extent of corporate disclosure in 
annual reports of Nigerian listed companies. Furthermore, we disaggregated corporate disclosure into three components. They include mandatory disclosure, voluntary disclosure and total disclosure. This was to allow for the determination of the association between firm structure variables and individual corporate disclosure variant.

Our results showed a positive and significant association between firm size and mandatory disclosure. The results also showed a negative but significant relationship between leverage and mandatory disclosure. Both leverage and firm size showed a positive and significant relationship with voluntary disclosure. Similarly, firm size was found to be positive and significantly related to total disclosure, while leverage revealed a negative but significant relationship with total disclosure. The combined effect of leverage and firm size showed a positive and significant relationship on total disclosure.

The findings suggest that companies depending on debts satisfy the needs of creditors through disclosing more information than purely equity financed firms. Our findings also revealed that large companies disclose more information as they are more subject to scrutiny by the public than small companies. In addition, large firms disclose more information at low costs than their small counterparts. This is because the incremental cost of supplying nonproprietary data to the public is likely to be minimal for large firms.

Based on our findings, we recommend that the Financial Reporting Council of Nigeria and other regulatory agencies should intensify efforts towards enforcement of companies' compliance with the requirement of IFRSs and other relevant statutory provisions. In addition, future empirical studies in this area should expand the number of years to include more recent years. This could be used to assess the trends of disclosure in order to confirm if there had been any improvement over time.

\section{References}

[1] Abdulrahman, A. (1998). Disclosure of corporate financial information in Malaysia. (Unpublished Doctoral Dissertation). University of Glasgow, Scotland, UK

[2] Abu-Nassar, M. (1993). The development of financial reporting in Jordan: a survey of prepares' and users' attitudes and reporting practices (Unpublished Doctoral Dissertation). University of Kent at Canterbury, UK.

[3] Adegbite, E., \& Nakajima, C. (2011). Corporate governance and responsibility in Nigeria. International journal of Disclosure and Governance, 8(3) 252-271.

[4] Adegbite, K., Amaeshi, O. \& Amao, E. (2011). The politics of shareholder activism in Nigeria. Journal of Business Ethics, 105 (3), 389-402

[5] Akinlabi, A. O., Hamed, B., \& Awoniyi, M. A. (2011). Corruption, foreign direct investment and economic growth in Nigeria: An empirical investigation. Journal of Research in International Business Management, 1 (9), 278-292.

[6] Akinlo, A. E. (2004). Foreign direct investment and growth in Nigeria: An empirical investigation. Journal of Policy Modeling, 26(5), 627-639.

[7] Alsaeed, K. (2006). The Association between firm-specific characteristics and disclosure: The case of Saudi Arabia. Managerial Auditing Journal, 21(5), 476-496.
[8] Al-Zarouni, A. (2008). Corporate Financial Disclosure in Emerging Markets: The case of the UAE (Doctoral Dissertation, Griffith University, UK). Retrieved from https://www120.secure.griffith.edu.au/.../AlZarouni_2009_02Thesis.

[9] Amao, O., \& Amaeshi, K. (2008). Galvanising shareholder activism: A prerequisite for effective corporate governance and accountability in Nigeria. Journal of Business Ethics, 82(1), 119-130.

[10] Beaver, W. (1968). The information content of annual earnings announcements. Journal of Accounting Research 6, 67-92.

[11] Buzby, S. L (1972). An empirical investigation of the relationship between the extent of disclosure in corporate annual reports and two company characteristics (Unpublished Doctoral Thesis). Pennsylvania State University, USA.

[12] Buzby, S. L. (1974). Selected items of information and their disclosure in annual reports. The Accounting Review, 49(3), 423-435.

[13] Camfferman, K., \& Cooke, T.E. (2002). An analysis of disclosure in the annual reports of UK and Dutch companies. Journal of International Accounting Research, 5(1), 3-30.

[14] Cerf, A. R. (1961). Corporate Reporting and Investment Decisions. Berkeley: University of California Press.

[15] Choi, F.D.S. (1973). Financial disclosure and entry to the European capital market. Journal of Accounting Research, 11 (2), 159-175.

[16] Clarke, T. (Ed.). (2004). Theories of corporate governance: The philosophical foundations of corporate governance. London: Routledge

[17] Cooke, T.E. (1992). The impact of size, stock market listing and industry type on disclosure in the annual reports of Japanese listed corporations. Accounting and Business Research, 22(87), 229-237.

[18] Eisenhardt, K. M. (1989). Agency theory: An assessment and review. Academy of Management Review, 14(1), 57-74.

[19] Fama, E. F., \& Jensen, M. C. (1983). Separation of ownership and control. Journal of Law and Economics, 26(3), 301-325.

[20] Gibbins, M., Richardson, A., \& Waterhouse, J. (1990). The management of corporate financial disclosure: opportunism, ritualism, policies, and processes. Journal of Accounting Research 28(1), 121-143.

[21] Gitman, L.J., Chad, J. \& Lawrence, J., (2009). Principles of Managerial Finance. $12^{\text {th }}$ ed. Boston Pearson International

[22] Greene, J. C. (2007). Mixed Methods in Social Inquiry. San Francisco, CA: John Wiley \& Sons.

[23] Healy, P. M., \& Palepu, K. G. (2001). Information asymmetry, corporate disclosure, and the capital markets: A review of the empirical disclosure literature. Journal of Accounting and Economics, 31(1-3), 405-440.

[24] Iatridis, G. (2008). Accounting disclosure and firms' financial attributes: Evidence from the UK stock market. International Review of Financial Analysis, 17 (2), 219-241.

[25] Ibrahim, L. (2014). Accounting information disclosure by selected Nigerian deposit money banks (Unpublished Master's Dissertation), Usmanu Danfodiyo University, Sokoto, Nigeria.

[26] Inyang, B. J. (2009). Nurturing corporate governance system: The emerging trends in Nigeria Journal of Business Systems, Governance and Ethics, 4(2), 1-13.

[27] Israel, G. D. (2013, October). Sampling the evidence of extension program impact. program evaluation and organizational development. IFAS, University of Florida. PEOD-5.

[28] Jensen, M., \& Meckling, W. (1976). Theory of the firm: Managerial behaviour, agency costs and ownership structure. Journal of Financial Economics, October, 305-360.

[29] Kiyanga, B. P. L. (2014). Corporate disclosure quality: A comparative study of Botswana and South Africa. Unpublished Master's Thesis, University of South Africa.

[30] Kothari, S.P. (2001). Capital market research in accounting. Journal of Accounting and Economics, 31(3), 105-231.

[31] Lang, M., \& Lundholm, R. (1993). Cross sectional determinants of analyst rating of corporate disclosures. Journal of Accounting Research, 31 (2), 246-271.

[32] Lawal, G. (2007). Corruption and development in Africa: Challenges for political and economic change. Humanity and Social Sciences Journal, 2(1), 1-7. 
[33] Lee, M. D. P. (2012). A review of the theories of corporate social responsibility: Its evolutionary path and the road ahead. International Journal of Management Reviews, 10(1), 53-73.

[34] Malone, D., Fries, C., \& Jones, T. (1993). An empirical investigation of the extent of corporate financial disclosure in the Oil and Gas industry. Journal of Accounting, Auditing and Finance, 3 (3), 249-273.

[35] Meek, G.C., Roberts, B. \& Gray, J. (1995). Factors influencing voluntary annual report disclosures by U.S., U.K. and Continental European multinational corporations. Journal of International Business Studies, 26 (3), 555-572.

[36] Moore, L., \& Buzby, S. (1972). The quality of corporate financial disclosure: A comment. Accounting Review, July, 581-584.

[37] Naser, K. (1998). Comprehensiveness of disclosure of nonfinancial companies listed on the amman financial market. International Journal of Commerce and Management, 8(1) 88-119.

[38] Okike, E., Adegbite, E., Nakpodia, F., \& Adegbite, S. (2015). A review of internal and external influences on corporate governance and financial accountability in Nigeria. International Journal of Business Governance and Ethics, 10(2), 65-185.

[39] Oliveira, L., Rodrigues, L.L., \& Craig, R. (2006). Firm-specific determinants of intangibles reporting: Evidence from the Portuguese stock market. Journal of Human Resource Costing and Accounting, 10(1), 11-33.

[40] Omran, M. \& El-Galfy, A.M. (2014). The theoretical perspective on corporate disclosure: A critical evaluation and literature survey. European Journal of Marketing, 8 (4) 257-286.

[41] Osemeke, L., \& Adegbite, E. (2014). Regulatory multiplicity and conflict: towards a combined code on corporate governance in Nigeria. Journal of Business Ethics, 90(4), 1-21.

[42] Owusu-Ansah, S. (1998a). The adequacy of corporate mandatory disclosure practices on emerging markets: A case study of the Zimbabwe stock exchange (Unpublished Doctoral Thesis). Middlesex University, London, UK.

[43] Owusu-Ansah, S. (1998b). The impact of corporate attributes on the extent of mandatory disclosures and reporting by listed companies in Zimbabwe. The International Journal of Accounting, 33(5), 603-631.

[44] Oyejide, T. A., \& Soyibo, A. (2001). Corporate Governance in Nigeria. Amao, O., \& Amaeshi, K. (2008). Galvanising shareholder activism: A prerequisite for effective corporate governance and accountability in Nigeria. Journal of Business Ethics, 82(1), 119-130.

[45] Parker, R.H. (1992). The macmillan dictionary of accounting, London: Macmillan.

[46] Qu, W. (2011). A study of voluntary disclosure by listed firms in China (Unpublished PhD Thesis). Deakin University, China.

[47] Shehata, N.F., Dahawy, K. \& Ismail, T. (2014). The relationship between firm characteristics and mandatory disclosure Level: When Egyptian accounting standards were first adopted. Mustang Journal of Accounting and Finance, 5, 85-103.

[48] Singhvi, S.S., \& Desai, H.B. (1971). An empirical analysis of the quality of corporate financial disclosure. The Accounting Review, 46 (1), 129-138.

[49] Solomon, J. (2013). Corporate governance and accountability. United Kingdom: John Wiley \& Sons.

[50] The Economist (2014, April 7). How Nigeria's economy grew by $89 \%$ overnight. Retrieved from http://www.economist.com/blogs/economist-explains.

[51] Umoren, A.O. (2009). Accounting Disclosures and Corporate Attributes (Unpublished Doctoral Thesis). Covenant University, Ota, Nigeria.

[52] Wallace, R. S.O., Naser, K., \& Mora, A. (1994). The relationship between the comprehensiveness of corporate annual reports and firm characteristics in Spain. Accounting and Business Research, 25(97), 41-53.

[53] Watson, A., P. Shrives, \& C. Marston (2002). Voluntary disclosure of accounting ratios in the UK. British Accounting Review 34 (4), 289-313.

[54] Wilson, I. (2006). Regulatory and institutional challenges of corporate governance in Nigeria post banking consolidation. Nigerian Economic Summit Group (NESG) Economic Indicators, 12(2), 1-10.

[55] World Bank (2011). Report on the observance of standards and codes (ROSC) Nigeria, Accounting and Auditing. Retrieved from http://www.worldbank.org/ifa/rosc_aa_nga.pdf.

[56] World Bank (2014). Report on the observance of standards and codes (ROSC) Nigeria, accounting and auditing. Retrieved from http://www.worldbank.org/ifa/rosc_aa_nga.pdf.

[57] World Population Prospect (2013). Retrieved from http://www.esa.un.org.

[58] Yamane, T. (1967). Statistics: An Introductory Analysis. New York: Harper and Row. 